\title{
MLH3 wt Allele
}

National Cancer Institute

\section{Source}

National Cancer Institute. MLH3 wt Allele. NCI Thesaurus. Code C50992.

Human MLH3 wild-type allele is located in the vicinity of $14 \mathrm{q} 24.3$ and is approximately 35 $\mathrm{kb}$ in length. This allele, which encodes DNA mismatch repair protein Mlh3, plays a role in DNA mismatch repair and genomic integrity maintenance. 